\title{
Positivistas e republicanos: os professores da Escola de Engenharia de Porto Alegre entre a atividade política e a administração pública (1896-1930)
}

\author{
Positivists and Republicans: the professors of the School of \\ Engineering in Porto Alegre between political activity and public \\ administration (1896-1930)
}

Flavio M. Heinz ${ }^{*}$

Resumo

A história da administração pública no sul do Brasil durante a Primeira República põe em evidência uma instituição de formação superior, a Escola de Engenharia de Porto Alegre, que, fundada em 1896, forneceu parte significativa dos quadros técnicos das secretarias e agências do estado nas décadas seguintes, notadamente da Secretaria dos Negócios de Obras Públicas (SOP). Neste artigo (1) faremos uma breve exposição do cenário político-institucional no sul do Brasil na transição do século XIX para o XX; (2) apresentaremos as linhas gerais do processo de organização da Escola de Engenharia de Porto Alegre; e (3) discutiremos alguns aspectos do percurso profissional, administrativo e político de seu grupo original de docentes e de seus primeiros diplomados.

Palavras-chave: Escola de Engenharia de Porto Alegre; engenheiros; Positivismo.

\section{Abstract}

The history of public administration in Southern Brazil during the so-called "First Republic" includes an institution of higher education, the School of Engineering in Porto Alegre, that was founded in 1896 and provided a major part of the cadre of technicians of state departments and agencies in the following decades, particularly of the state's Department of Public Works. In this paper the author (1) briefly discusses the politicalinstitutional scenario in Southern Brazil during the transition from the $19^{\text {th }}$ to the $20^{\text {th }}$ century, then (2) sketches the process of organization of the School of Engineering in Porto Alegre, and finally (3) presents some aspects of the professional, administrative and political career of the School's original group of professors and its first graduates. Keywords: School of Engineering in Porto Alegre; engineers; Positivism.

\footnotetext{
* Departamento de História e Programa de Pós-Graduação em História da Pontifícia Universidade Católica do Rio Grande do Sul (PUC-RS). Av. Ipiranga, 6681, Prédio 3, 4º andar, Sala 408. 90619 900 Porto Alegre - RS - Brasil. flavio.heinz@pucrs.br
} 
O Brasil precisa cada vez mais de homens da tua estatura moral e do teu poder materialisador. Facts and not words. Foi esse o teu lemma, e será a divisa salvadora do paiz. Mais alguns da tua tempera, e muitos mais, em outras e outras espheras de actividade, e pouco a pouco se canalisará a admiração da mocidade para a verdadeira élite. Intelligencia, caracter e acção é a excelsa trindade dominadora, sem a qual não há progresso reale completo. Coussirat Araújo, no seu mundo, foi digno e bello exemplo para a nova hero-worship.

Sampaio Ferraz ${ }^{1}$

\section{Estado E POLÍticA NO SUL Do BRASIL, FINS DO SÉcUlo XIX ${ }^{2}$}

Em um texto de certa repercussão sobre o aparecimento da perspectiva desenvolvimentista e do Estado-providência no país, Alfredo Bosi indicava a presença, ainda em fins do século XIX, de uma matriz positivista que, mais tarde, influenciaria o modelo de desenvolvimento brasileiro do pós- $1930 .{ }^{3} \mathrm{Nes}-$ te se perceberia o traço do positivismo político, instrumental e militante, que os dirigentes do Partido Republicano Riograndense haviam implantado no sul do país, na esteira do golpe republicano de novembro de 1889, mas, principalmente, a partir da Constituição estadual de 14 de julho de 1891 e da vitória na guerra civil dita Federalista. ${ }^{4}$ A nova Constituição garantira as condições jurídicas e institucionais para a assunção da nova elite do poder, e a vitória armada sobre os opositores assinalava o início da hegemonia dos republicanos de Júlio de Castilhos no âmbito estadual.

O advento da República no Brasil, em novembro de 1889, é marcado por características gerais bastante conhecidas: agitação antimonárquica nos meios militares, notadamente nas escolas, entre aspirantes e jovens oficiais; iniciativa militar na deflagração do golpe republicano e na implantação do novo regime; afastamento do núcleo militar e retomada da hegemonia política civil em poucos anos; controle do espaço político e das posições do Estado por grupos pertencentes aos partidos republicanos de cada estado, em boa parte recuperando para suas hostes membros da elite política do regime deposto e acomodando facções e grupos rivais na estrutura partidária; baixa competitividade política do regime, que permanecerá por quase quatro décadas sem o aparecimento de partidos de oposição consistentes; descentralização política e administrativa, com grande autonomia dos poderes estaduais. No caso do Rio Grande do Sul, a influência de outros fatores sobre essas características teria 
garantido uma configuração distinta às práticas políticas desenvolvidas pelo grupo republicano: (1) a transição da Monarquia para a República no estado não se fizera, como em muitas partes do país, pelas mãos de militantes republicanos associados a membros do velho Partido Liberal, num caso exemplarmente malsucedido de reconversão partidária e adesismo ${ }^{5}$ revolucionário. Com efeito, uma clara clivagem estabelecera-se antes da proclamação entre os jovens republicanos do PRR e as lideranças do outrora forte Partido Liberal que, sob a monarquia, mantivera a hegemonia política do estado por várias décadas. " $\mathrm{O}$ caráter 'jacobino' dos militantes republicanos do sul” " 6 seria testado na conjuntura da transição, quando estes se opuseram abertamente à composição com os Liberais para a partilha do poder no novo regime, criando as condições para o aparecimento de um raro caso regional de constituição de uma oposição partidária ao longo da Primeira República no Brasil; (2) o 'jacobinismo’ dos jovens republicanos rio-grandenses era semelhante àquele dos jovens oficiais que haviam conspirado contra a monarquia na Corte, e poderia ser inicialmente explicado pela relativa coesão ideológica que a presença doutrinária do positivismo garantia. Tal como fizera com os opositores militares à monarquia, o positivismo, aqui tomado numa ampla gama de significados, mais políticos que filosóficos, é verdade, e que também estivera presente em outros estados, mas com menor impacto na formação ou mobilização da elite política, assegurava aos jovens republicanos uma linguagem, um conjunto de propostas coerente, identificando-os como grupo e os posicionando em relação a outros grupos políticos; (3) a esse 'laço' ideológico com os militares - basicamente com aqueles cujas carreiras nacionais conheceram rápida ascensão a partir do advento da República -, associava-se uma forte ligação pessoal dos militares com o estado que, por sua condição de fronteira e pela consequente concentração, nela, de tropas nacionais, era etapa da carreira de boa parte dos oficiais brasileiros (e Porto Alegre também possuía sua Escola Militar, foco de agitação republicana); de toda forma, vínculos aqui constituídos garantiram ao grupo republicano do Rio Grande do Sul o apoio do núcleo militar nacional por longo tempo. ${ }^{7}$ Ainda, militantes republicanos e jovens militares, notadamente aqueles de inclinação positivista, partilhavam certa desconfiança em relação ao liberalismo clássico das elites regionais brasileiras, bem como a simpatia por um modelo de ação pública que combinasse graus variados de autoritarismo, intervenção estatal e dirigismo econômico, como terminaria por ocorrer no Rio Grande do Sul.

O “ideário reformista, comum aos tenentes e aos líderes do Partido Republicano Riograndense, irá fundamentar o programa da Aliança Liberal vito- 
riosa em outubro de 30" (Bosi, 1992, p.280). Segundo essa interpretação, na raiz das transformações brasileiras pós-1930 estaria a experiência política e administrativa de quase quarenta anos dos republicanos rio-grandenses - fortemente antiliberal nas práticas econômicas e autoritário na esfera política -, e o positivismo teria sido o núcleo intelectual e doutrinário dessa experiência. ${ }^{8}$ A tese de Bosi resta a ser demonstrada empiricamente, mas ela sugere pistas para se compreender o perfil da formação dos quadros técnicos - e políticos - da administração regional no período, iluminando o percurso de criação e consolidação da Escola de Engenharia ao longo da Primeira República.

\section{A Escola De ENGENHARIA}

Ao comentar a baixa participação de ministros de Estado com origem em profissões técnicas nos últimos anos do Império, num texto de referência sobre os engenheiros na história do Brasil moderno, José Luciano Mattos Dias sugere que a proclamação da República, graças ao envolvimento de intelectuais positivistas e militares, poderia ter modificado esse quadro, com a abertura de oportunidades na administração pública para indivíduos de formação técnica. E segue o autor:

a momentânea hegemonia do pensamento positivista não foi capaz, contudo, de sustentar um projeto de 'direção técnica do Estado'. O curto período de intervenção militar e de política econômica não-ortodoxa, além disso, não poderia ter dado oportunidade à criação e controle de novos órgãos técnicos no Estado ou de ampliação de postos na indústria. (Dias, 1994, p.18)

E o autor concluiria, com uma nota ao parágrafo, afirmando que as experiências militares ou positivistas nas administrações estaduais raramente tinham podido formular propostas para além do campo da educação básica. Citava, contudo, o "caso excepcional do Rio Grande do Sul, onde a adoção, pelas elites locais, do positivismo poderia ter levado adiante um projeto de administração 'científica"'. 9

Com efeito, se algum projeto de administração 'científica' existiu no Rio Grande do Sul, então seu núcleo intelectual esteve na Escola de Engenharia de Porto Alegre, organizada em agosto de 1896 por iniciativa de um grupo de engenheiros militares residentes nessa cidade. ${ }^{10}$ Sem recursos para fazer frente às suas primeiras necessidades, a Escola acabou contando com doações privadas para sua instalação, e a inauguração ocorreu em janeiro de 1897 (Hassen; 
Ferreira, 1996, p.15). Legado maior dos positivistas religiosos no tema educação, a Escola foi "planejada segundo o projeto comtiano de universidade técnica". ${ }^{11}$ Demarcando-se do perfil de outras instituições superiores do período, a Escola evitava, para Gertz, "o bacharelismo, típico do ensino superior brasileiro da época e opt[ava] por uma escola prática, inserida no contexto social circundante". ${ }^{12} \mathrm{E}$ esse autor concluiria assinalando que o modelo escolhido não fora o da escola politécnica francesa, "mas sim o da Technische Hochschule alemã e do modelo norte-americano". O sistema norte-americano do Land-Grant College ${ }^{13}$ é apontado, também, como modelo para a criação da Escola de Engenharia.

Para além de tentar localizar uma matriz inequívoca, essas referências parecem indicar as diferentes filiações intelectuais dos membros da Escola e de seus primeiros investigadores, mas provavelmente também revelam a superposição de 'escolas' e sistemas que tinham, em comum, a defesa do lugar central da técnica - e do aprendizado técnico - na formação profissional, e a refutação da orientação tipicamente 'literária' e jurídica do ensino básico e superior na tradição luso-brasileira. O caráter 'prático' e 'técnico' da formação da Escola de Engenharia não deixaria de ser sempre reivindicado, seja pelo evidente esforço no sentido da estruturação do ensino técnico-profissional uma das prioridades da nova Escola -, seja na própria formação dos engenheiros. Assim, na revista Egatea ou nos Relatórios Anuais da Escola, há farta provisão de interpretações sobre a profissão e sua contribuição para o desenvolvimento da sociedade e do país, como neste trecho de um artigo de Waddel e Barrington (a tradução de textos de autores norte-americanos e ingleses era frequente) sobre a profissão de Engenheiro:

Pode-se censurar aquelles que ... proclamam ser ella de muita a mais importante das profissões liberaes, a mais scientífica de todas e que os admiraveis progressos da humanidade nos últimos cincoenta annos são devidos essencialmente à energia e à habilidade dos engenheiros? ${ }^{14}$

A Escola iniciará, já nos seus primeiros anos, um forte movimento de expansão de cursos técnicos e preparatórios que terá imediato impacto sobre suas atividades e sobre o apoio que receberá dos poderes públicos. Em 1900, é criado um curso preparatório para candidatos à Escola e a outras faculdades, curso que receberá alguns anos mais tarde o nome de Júlio de Castilhos, em homenagem ao líder republicano morto em 1903. O Instituto Júlio de Castilhos oferecia cursos primário e ginasial, com três e seis anos, respectivamente, e 
incluía em seu currículo artes manuais e instrução militar. Nesse momento, o objetivo da Escola seria "preparar os meninos para a vida prática dando-lhes tal educação que os habilite a seguir a carreira que preferirem, com conhecimentos sólidos e práticos, e não com a educação literária, defeituosa e incompleta, dada em geral pelos ginásios..." (Relatório de 1911, apud Hassen; Ferreira, 1996, p.60; grifos nossos).

Se o Instituto Júlio de Castilhos preparava os postulantes à Escola e, possivelmente, a carreiras 'de elite', em 1906 era criado o Instituto Técnico Profissional - nomeado inicialmente Escola Benjamin Constant, em homenagem ao líder republicano e professor da Escola Militar do Rio de Janeiro -, e que mais tarde se chamaria Instituto Parobé (1917), destinado à formação de meninos de famílias pobres. Construções mecânicas, marcenaria e carpintaria, artes gráficas e artes do edifício eram as seções do Instituto, cujo ensino era gratuito e realizado em turnos diurno e noturno. ${ }^{15}$ Em 1908, criava-se o Instituto de Eletrotécnica (mais tarde Instituto José Montaury, em 1922), que ministrava um curso de engenheiro mecânico-eletricista e um curso técnico de montadores mecânicos-eletricistas. Ainda nesse ano era instalado o Instituto Astronômico e Meteorológico, sem vocação de formação escolar, que estaria voltado ao estudo do clima e estabeleceria uma vasta rede de estações que estão na origem dos serviços de climatologia hoje existentes no estado.

As relações entre a Escola de Engenharia e o governo do Estado eram então muito cordiais (Franco; Morosini, 1992, p.25-27). Recursos públicos em abundância financiavam a construção de instalações e a expansão da Escola, notadamente a construção de um imponente prédio em estilo Renascença alemã para abrigar o Instituto Júlio de Castilhos. Contudo, a percepção de um vínculo privilegiado entre o governo do estado e a Escola parecia se instalar e era desmentida pelos administradores, como se depreende deste trecho do relatório apresentado pelo diretor João José Pereira Parobé em 2 de abril de 1908, relativo ao ano de 1907:

A situação financeira da Escola, se não é lisongeira, não deixa de ser satisfatória, pois as receitas do Instituto de Engenharia, Instituto Eletro-técnico e gymnasial Júlio de Castilhos, cujo ensino é remunerado, dão para as despesas. Como vereis pelo Relatório annexo do illustre secretário, a lenda de que a Escola de Engenharia era a preferida pelo poder público, do qual recebia gordos auxílios, foi desfeita pois os seus Institutos de ensino remunerados tem recebido menos do que muitos absolutamente, menos do que todos tendo em vista a natureza do ensino neles ministrado... ${ }^{16}$ 
Não obstante, uma taxa profissional equivalente a $2 \%$ da arrecadação do estado seria criada ainda em 1908, durante o governo Carlos Barbosa. Os valores obtidos seriam direcionados, por um prazo de dez anos, à Escola de Engenharia. No ano seguinte, a Assembleia dos Representantes (deputados) elevaria essa taxa a $4 \%$, garantindo importantes recursos para a Escola (os $2 \%$ adicionais deveriam ser aplicados com a implementação do ensino agronômico e veterinário em caráter técnico e profissional). O impacto da expansão da Escola e das oportunidades oferecidas, notadamente na estruturação do ensino técnico-profissional, produzira seus efeitos junto às autoridades, a ponto de o presidente do estado, Borges de Medeiros, declarar em 1908: "Reputo o facto mais importante dos meus dez annos de governo o concurso que prestei à installação do Instituto técnico e profissional". ${ }^{17}$

$O$ vínculo da Escola de Engenharia com o estado se materializaria então em três níveis: na identidade comum assegurada pelo positivismo e pelo vínculo com o PRR; pela percepção estratégica da Escola "como agente de fomento do desenvolvimento econômico e tecnológico" no estado e, finalmente, pela ajuda financeira pública à Escola. "Em inúmeros documentos aparecem referências elogiosas ao governo do Estado e a seus líderes políticos, sendo previsto nos estatutos da EPPA homenagens e indicações de patronos para os institutos" (Alves, 2008, p.256). A preocupação com o ensino técnico e profissional seguia existindo, como na criação em 1912 do Instituto de Agronomia e Veterinária - rebatizado Instituto Borges de Medeiros em 1917, em homenagem ao presidente do estado -, que também deveria prever a formação de dois cursos, um teórico-prático, para formar agrônomos e veterinários, e outro exclusivamente prático, para formar agricultores práticos com conhecimentos de veterinária. Nos anos seguintes, a rede de cursos, na sua maioria de caráter técnico-profissional, foi sendo expandida: Instituto de Zootecnia, Instituto Experimental de Agricultura, Patronato Agrícola Pinheiro Machado, depois Instituto Pinheiro Machado (em homenagem ao senador pelo PRR assassinado em 1915), Estações Experimentais de Agricultura, Instituto de Educação Doméstica e Rural, teciam uma ampla rede de ensino e extensionismo rural, com filiais e estações experimentais em inúmeras cidades do interior do estado e que seriam em boa parte absorvidas pelo poder público nas décadas subsequentes. Ainda, uma Escola Industrial Elementar e o Instituto de Química Industrial completavam o quadro do ensino técnico-profissional constituído pela Escola.

Da impressionante rede criada pela Escola de Engenharia, os cursos superiores representavam uma parte menor, embora muito prestigiosa: enge- 
nheiros civis e mecânicos-eletricistas, nos Institutos de Engenharia e de Eletrotécnica (Instituto Montaury, em homenagem ao intendente de Porto Alegre), e engenheiros-agrônomos e veterinários, a partir de 1922, no Instituto Borges de Medeiros. Contudo, é a vasta rede de ensino profissional que assegura presença importante da Escola nos espaços políticos e na imprensa, garantindo, de certa forma, a tarefa de 'incorporação do proletariado à sociedade', uma sempre lembrada, mas imprecisa, diretriz positivista que os responsáveis do Partido Republicano Riograndense parecem ver se realizar. Em 1928, a Escola de Engenharia já diplomara 425 profissionais, quase metade deles $(48,9 \%)$ engenheiros civis, aproximadamente 1/7 do total engenheiros-agrônomos, e outro 1/7 engenheiros-mecânicos, além de 581 formados em cursos técnicos profissionais (Macedo, 1993, p.125).

Assim, uma iniciativa privada, e que seguiu sendo gerida de fora dos órgãos públicos ao longo das primeiras décadas do século XX, lançou as bases de parte substancial da estrutura do estado no campo do ensino técnico e de assistência e extensão rural. Embora não se possa negar a capacidade de indução que a concessão de subsídios públicos pode oferecer, a leitura de relatórios e memórias dos principais representantes da Escola de Engenharia aponta para a construção de uma agenda própria, de um grupo intelectual e politicamente convergente, agenda em evidente sintonia com as aspirações intelectuais e as necessidades dos homens de Estado.

\section{Carreiras públicas, CARreiras De ENGenheIros ${ }^{18}$}

Parte significativa dos egressos da Escola de Engenharia e vários entre seus professores acabariam sendo incorporados ao quadro de funcionários do estado, notadamente da Secretaria de Negócios de Obras Públicas (SOP), a mais importante Secretaria de Estado do Rio Grande do Sul durante a Primeira República. ${ }^{19}$

De 165 funcionários da SOP repertoriados no período que vai de 1894 a $1930,{ }^{20} 41$ foram diplomados pela Escola de Engenharia e nove eram professores da instituição. Entre os professores, quatro diretores da Escola foram secretários de Obras Públicas, um sob a monarquia (Álvaro Nunes Pereira, $1^{\circ}$ diretor da Escola) e três sob a República. Os três professores da escola que assumiram a posição de secretário de Obras Públicas - João José Pereira Parobé (1891-1906 e 1914-1915), Cândido José de Godoy (1908-1912) e Ildefonso Soares Pinto (1918-1923) - a ocuparam durante um total de 28 anos.

Marcante na história da SOP, desde seus primeiros momentos sob a Re- 
pública, é a presença em seus quadros de simpatizantes da doutrina positivista, num período de “"polarização de tendências profissionais' entre positivistas políticos e religiosos” (Soares, 1998, p.172). Os positivistas religiosos seriam, em geral, "militares, engenheiros em diversas especialidades, médicos ou elementos do magistério, preferencialmente da área tecnológica. Em geral ortodoxos, aceitavam integralmente a orientação do Apostolado Positivista do Brasil”, ao passo que os positivistas políticos seriam "elementos da área política: bacharéis em Direito, magistrados, parlamentares e jornalistas. Adotando as soluções políticas do Positivismo, alheavam-se das recomendações religiosas e não pertenciam ao Apostolado". Ainda, o núcleo de adeptos mais atuantes desse grupo seria composto pelos "mais categorizados servidores da Secretaria de Obras Públicas, a começar por Felizardo Jr., Faria Santos, Torres Gonçalves e Frederico Westphalen" (ibidem, p.172-173).

\section{ENGENHEIROS, FUNCIONÁRIOS E POSITIVISTAS}

Embora nem todos os engenheiros-funcionários aqui analisados possam ser definidos como 'positivistas' em sentido doutrinário, a maioria compartilhava uma série de códigos culturais impregnados por aquilo que Nelson Boeira classificou como positivismo político e positivismo difuso - como atesta o uso de saudações positivistas, como "Saúde e Fraternidade", nas cartas entre funcionários e autoridades de todos os níveis. Não obstante, pelo menos quatro professores dos primeiros anos da Escola de Engenharia eram positivistas religiosos e atuaram na administração pública no período. Um deles, João Simplício Alves de Carvalho, teve atuação administrativa reduzida, assumindo apenas a titularidade da Secretaria da Fazenda em 1930, mas atuou intensamente no campo político e na vida da Escola de Engenharia. ${ }^{21}$ Os três outros, Joaquim José Felizardo Jr., João Luiz de Faria Santos e Ildefonso Borges Toledo da Fontoura, fariam carreira, sobretudo, na administração pública. Pouco expressivo no âmbito regional, o positivismo religioso seguia orientações da Igreja Positivista do Brasil (IPB) e, no Rio Grande do Sul, tal como acontecia no âmbito nacional, "a maior parte dos positivistas religiosos ... também tinha formação em engenharia - diferentemente dos políticos gaúchos simpáticos ao positivismo, quase todos advogados". ${ }^{22}$ Junto àquele que é talvez o mais destacado apóstolo do positivismo religioso no Rio Grande do Sul, Carlos Torres Gonçalves, um dos poucos engenheiros notórios do estado que não atuou como professor na Escola de Engenharia, Faria Santos e Felizardo Jr. "realizaram seus estudos na Escola Politécnica do Rio de Janeiro ao longo das últimas décadas do século 
XIX. Todos os três eram funcionários concursados da Secretaria de Obras Públicas ... onde exerceram importantes funções ao longo da República Velha" (Pezat, 1998, p.145). Para Pezat, a SOP constituiu um reduto de positivistas religiosos no interior da máquina administrativa rio-grandense.

Um episódio ocorrido com Faria Santos e narrado por esse autor dá a ideia do perfil mais 'ideológico' dos positivistas religiosos face aos demais simpatizantes do positivismo no sul do país. Faria Santos, que estivera à frente do executivo municipal durante dez meses, de janeiro a outubro de 1896, quando ainda não havia ainda ingressado na IPB e, portanto, ainda não seguia as diretrizes do apostolado, foi convidado por Carlos Barbosa, presidente do estado (1908-1913), para compor seu secretariado, como titular da SOP. O funcionário, agora positivista religioso atuante, acabou "não aceitando, em função de conselho de Teixeira Mendes [dirigente da Igreja Positivista do Brasil], que lembrou-lhe que os positivistas religiosos não deveriam exercer cargos políticos, restringindo-se às funções administrativas". Faria Santos permaneceu na chefia da Diretoria de Viação Fluvial de 1896 até sua aposentadoria, em 1913.

Outra faceta da atuação dos positivistas religiosos na SOP pode ser percebida no grau de 'militância' dessa Secretaria na difusão dos símbolos do positivismo e de seus propagadores locais, sobretudo na fixação da imagem de Júlio de Castilhos como protetor e propagador da doutrina. Essa curiosa 'militância' exigia uma espécie de adaptação entre as injunções da Igreja Positivista e as necessidades de reconhecimento do papel central de Castilhos no Rio Grande do Sul. Assim, por exemplo, como em 1904, quando das críticas públicas formuladas pela nova direção da IPB ao líder político, havia pouco falecido, pelo fato de nunca ter assumido plenamente o positivismo religioso. Com efeito, pressionados por um lado pela posição da Igreja Positivista e, por outro, pelo necessário respeito à imagem e ao patrimônio político deixado por Castilhos no estado, os engenheiros-funcionários positivistas da SOP optaram por uma solução híbrida, em que às loas habituais às virtudes do chefe seguiam-se breves críticas à sua "indeterminação quanto ao positivismo". ${ }^{23}$ Para Soares (1998, p.172), os ativistas positivistas atuantes na Secretaria de Obras Públicas contavam com

notória simpatia do partido republicano, tudo ao arrepio das recomendações de Comte, quanto à independência moral dos elementos da classe sacerdotal frente ao poder público. Mesmo com essa velada interdição a pronunciamentos contestatórios de quaisquer medidas do Governo, eles não deixavam de manifestar-se. Tal situação faz supor que as naturezas mais sensíveis tivessem de 
vencer constrangimentos para coonestar a necessidade de independência e a subordinação formal.

Segundo Leal (2006, p.252-264), coube ainda à SOP, e ao núcleo religioso formado por Faria Santos, Felizardo Jr. e Carlos Torres Gonçalves, as tarefas de financiamento, execução e acompanhamento dos projetos que envolviam a figura de Castilhos: o monumento fúnebre - projeto do artista positivista Décio Villares, executado por Felizardo Jr. -, o monumento cívico, também de Villares, erguido dez anos depois da morte de Castilhos, na praça central de Porto Alegre, junto às sedes dos poderes do estado e, finalmente, a condução do projeto (não realizado) de produção de 67 bustos em bronze de Castilhos para serem colocados em cidades do Rio Grande do Sul.

A rede que reunia engenheiros positivistas - fossem eles ativos ou não na IPB -, militares e a SOP pode ser verificada em um documento intitulado "Subsídios positivistas", mantido e atualizado pelo professor da Escola e funcionário da SOP, Joaquim José Felizardo Júnior, arrolando 110 nomes de doadores - constando profissão e quantia doadas -, os quais, ao longo de cinco anos (1901-1905), contribuíram para custear atividades do núcleo de positivistas religiosos de Porto Alegre e, mais tarde, para financiar a construção da Capela Positivista. Do total de doadores, trinta são engenheiros, 21 militares (dos quais alguns engenheiros-militares atuantes na Escola de Engenharia de Porto Alegre, como João Simplício Alves de Carvalho, Juvenal Octaviano Müller e Lino Carneiro da Fontoura) e cinco agrimensores (formação ligada à engenharia), além de pelo menos um estudante da Escola, Álvaro Rodrigues Leitão. Mas se o total de engenheiros e militares (51 sobre 110) é significativo, mais ainda é o fato de as profissões aparecerem distribuídas de forma irregular no conjunto, com forte concentração de nomes de engenheiros e militares na parte inicial - ou primeiros anos - da lista. Assim, dos 24 primeiros nomes, 17 são de engenheiros (três de militares), o que corresponde, as duas profissões reunidas, a $83 \%$ do total. Entre os primeiros cinquenta nomes, há 25 engenheiros (e oito militares), o que perfaz 66\% do total. Além disso, entre os 110 doadores positivistas, apenas quatro declararam-se comerciantes e outros dois 'capitalistas', para retomar-se uma expressão da época. ${ }^{24}$

O que essa listagem nos revela? Que uma rede densa de relações associava esses indivíduos ao longo de um percurso comum, que passava pela formação militar, pela frequência às salas de aula da Escola, pelos gabinetes da SOP e, finalmente, pela experiência das reuniões periódicas de comentários do Catecismo Positivista. A presença de uma esmagadora maioria de engenheiros 
nas primeiras posições da lista sugere um protagonismo desse grupo profissional - e, por decorrência, da Escola de Engenharia - entre os positivistas religiosos do Rio Grande do Sul.

\section{ENGENHEIROS E POLÍ́TICOS}

Outras carreiras públicas não se definiram pela ocupação de postos administrativos, mas sim de responsabilidades políticas assumidas nos vários níveis do poder legislativo, em completa adesão ao projeto político do Partido Republicano Riograndense. Assim, carreiras contemporâneas à fase de criação e consolidação da Escola, bem como trajetórias posteriores, confirmam a presença de um importante capital político associado à Escola e à profissão. Um dos fundadores da Escola, Juvenal Octaviano Miller, foi eleito deputado estadual em 1901, depois deputado federal (1903-1905), e foi nomeado vice-presidente do estado em 1908, posição que ocupava quando faleceu, no ano seguinte. Outro dos fundadores e contemporâneo de Juvenal Miller na Escola Militar do Rio Grande do Sul, João Simplício Alves de Carvalho, deputado estadual de 1901 a 1908, e federal de 1909 a 1929, secretário da Fazenda do governo estadual de Vargas, em 1930, deputado nacional constituinte em 19331934, e deputado federal em 1935-1937, fora eleito para a direção da Escola em 1915 e nessa posição permaneceu até 1922.

João José Pereira Parobé foi constituinte estadual em 1891, secretário de estado de Obras Públicas de 1891 a 1906 e de 1914 a 1915, e deputado estadual de 1909 a 1912. Também constituinte em 1891, Manoel Theophilo Barreto Vianna, diretor interino da Escola durante o período 1915-1922, foi deputado estadual no período de 1897 a 1927, tendo sido a partir de 1905 seu presidente, sucessivamente reconduzido ao cargo. Outro constituinte de 1891, Luiz Englert, dirigiu o Instituto de Engenharia e foi deputado estadual no período de 1891 a 1912. Nos casos acima referidos, a participação da Constituinte estadual não é um feito menor. A Constituição estadual republicana de 14 de julho de 1891, reconhecida como de 'inspiração positivista', pode ser definida como de caráter 'fundacional' para os militantes republicanos do Rio Grande do Sul. Ela definiu uma estrutura de poder fortemente centralizada, autoritária, em que o parlamento estadual tinha funções de análise e aprovação do orçamento, e esteve por quatro décadas em claro desacordo com a Constituição federal brasileira em inúmeros pontos.

João Vespúcio de Abreu e Silva foi fundador da Escola (1896) e deputado estadual entre 1905 e 1909, e federal de 1909 a 1920. Ildefonso Soares Pinto, 
engenheiro militar formado no Rio de Janeiro e professor da Escola desde 1911, onde lecionou Física, Mecânica Racional e Finanças, diplomou-se também bacharel em Direito (1912); foi nomeado diretor de A Federação, principal órgão do partido Republicano Riograndense, em 1913, mesmo ano em que se elegeu deputado estadual; em 1915 assumiu vaga como deputado federal, posição que ocuparia até 1918, quando foi nomeado secretário de Obras Públicas do estado, posição que seguiria ocupando até 1924, quando assumiu a direção da Viação Férrea do Rio Grande do Sul. Candido José de Godoy, engenheiro formado pela École des Ponts et Chaussées em 1876, ocupou vários cargos na administração pública ligada à viação férrea e aos portos do estado e foi nomeado, em 1908, para a secretaria de Obras Públicas, na qual permaneceu até 1913, ocupando concomitantemente a secretaria da Fazenda do governo Carlos Barbosa. Em 1914, foi nomeado pelo governo federal chefe da Comissão Fiscal do Porto do Pará e, em seguida, inspetor dos Portos, Rios e Canais do Brasil.

Em todos esses casos, uma clara identificação com o regime republicano e, sobretudo, com o seu núcleo castilhista, estava presente. Uma das poucas exceções verificadas foi o primeiro presidente da Escola de Engenharia, Álvaro Nunes Pereira. Sua condição de 'funcionário' da Monarquia - ocupara o cargo de diretor da Repartição de Obras - e os vínculos pessoais com o antigo regime - era filho do Gal. Vasco Alves Pereira, Barão de Livramento - possivelmente o colocaram em desvantagem frente a um grupo de engenheiros mais jovem e ideologicamente coeso. A crônica da Escola sugere que a escolha de Álvaro Nunes Pereira para o cargo tivera origem numa indicação de Júlio de Castilhos - com quem o engenheiro aparentemente teria relação de amizade - aos jovens militares fundadores da Escola. A incorporação de Álvaro Nunes Pereira asseguraria a presença de um engenheiro civil num grupo então composto exclusivamente de engenheiros militares. Trata-se de uma explicação plausível para a presença à frente da Escola de alguém que não pertencia ao núcleo de militantes republicanos, logo sem a legitimidade conquistada no processo político recente - que incluía a participação na queda da monarquia na província e na sangrenta guerra civil de 1893-1895. Em atrito com um dos fundadores da Escola, o militar positivista Juvenal Octaviano Miller, em 1898, esteve no centro de uma crise que o levou a solicitar a demissão do cargo.

Os cinco componentes do núcleo fundador da Escola (Miller, Carvalho, Meira, Fontoura e Abreu e Silva) haviam sido professores da Escola Militar do Rio Grande do Sul, em Porto Alegre, e eram também contemporâneos de formação militar. Nascidos entre 1865 e 1869, haviam chegado à idade adulta e à condição de aspirantes nos anos de agitação republicana que antecederam o 
golpe de 1889. Miller e Carvalho encontram-se, por exemplo, entre os 42 alunos da Escola Militar do Rio Grande do Sul signatários de telegrama de felicitações a Joaquim Nabuco, em setembro de 1887, por ocasião de sua eleição como deputado por Pernambuco. Por ordem do ministro da Guerra, Delfino Ribeiro da Luz, o comandante da Escola Militar impôs pena de prisão de vinte dias aos signatários. ${ }^{25}$

A ordem do dia escolar de trinta fez publico ter sido mandado cumprir no estado maior do Décimo Terceiro Batalhão de Infantaria a pena de vinte dias de prisão, imposta pelo conselho de disciplina a que foi submettido por ter dirigido um telegramma de felicitações ao Doutor Joaquim Nabuco, censurando o governo. ${ }^{26}$

Pela ordem do dia do Commando da Escola numero cincoenta e quatro de trinta de setembro de 1887, foi mandado cumprir no Estado Maior do 13 Batalhão d'infantaria a pena de vinte dias de prisão imposta pelo Conselho de disciplina a que foram submettidos os alumnos desta Escola por terem dirigido um telegramma de felicitação ao Deputado Joaquim Nabuco, o mesmo Conselho o julgando no número d'aquelles em que recae mais responsabilidade. Por outra ordem do dia do mesmo Commando, numero cincoenta sete de vinte e um de Outubro [de 1887] foi excluído da Escola e do estado effectivo desta Companhia, visto achar-se comprehendido no artigo 47 do regulamento em vigor. ${ }^{27}$

Esta e outras experiências provavelmente fortaleceram laços de amizade e camaradagem entre os engenheiros militares aqui analisados. Segundo Paulo Pezat, Miller teria escrito carta a Miguel Lemos, apóstolo da Igreja Positivista do Brasil, em outubro de 1896, afirmando sua disposição de criar, com outros colegas de magistério na Escola Militar de Porto Alegre, uma escola voltada à formação de engenheiros. Na carta, Miller solicitava a Miguel Lemos "um programa que valorizasse os aspectos práticos do ensino". ${ }^{28} \mathrm{O}$ outro apóstolo da IPB, Teixeira Mendes, elaboraria um programa que acabou não sendo aprovado em sua integralidade em virtude da oposição de colegas de Juvenal Miller.

Mais velhos, talvez no limite superior de outra geração, Parobé e Barreto Vianna eram os decanos da geração de engenheiros-militares que marcaria a criação da Escola, e encarnavam a experiência necessária e a estabilidade desejada em período de rápida mudança institucional e acelerada renovação geracional. Ainda que também tivessem se dedicado a atividades políticas e administrativas (Barreto Vianna dirigiu a pouco competitiva Assembleia dos Representantes do estado do Rio Grande do Sul por mais de duas décadas), suas carreiras ficariam associadas, no círculo social republicano, ao sucesso do 
empreendimento Escola de Engenharia, com a contínua expansão da instituição, o que se estenderia até o final da segunda década do século.

Por fim, alguns comentários sobre casos de engenheiros formados pela Escola de Engenharia e que acabaram tornando-se professores da própria Escola, seguindo posteriormente algum tipo de carreira na administração pública. Citemos, inicialmente, três professores de muito destaque na vida da Escola nas décadas de 1910 e 1920:

a) João Lüderitz, da turma de 1904, ingressou no quadro docente da Escola em 1906, mesmo ano em que assume a direção do Instituto Técnico-Profissional (depois Instituto Parobé), à frente do qual permaneceria até 1920. Diretor de Agricultura, Indústria e Comércio da Secretaria de Obras Públicas, no governo estadual de Vargas, em 1930. Presente durante toda a década de 1920 à frente das discussões nacionais em torno da legislação específica do ensino técnico e profissional, e da implementação de um sistema de ensino profissional no país, foi indicado por Vargas, em 1942, 1º diretor-geral do recém-criado Serviço Nacional de Aprendizagem Industrial (Senai);

b) Adolpho Alfredo Stern, nascido em Riga, Letônia (então território russo), em 1880, formado pela Escola na turma de 1909, ingressou no ano seguinte como docente, onde faria uma carreira exitosa e seria o responsável por diferentes matérias; em 1928, chegou ao Conselho Municipal de Porto Alegre, vindo a falecer em 1929;

c) Ladislau Coussirat Araújo, nascido em 1889, era da turma de 1912 da Escola. Ingressou no quadro docente da instituição no ano seguinte, assumindo, em 1918, como Engenheiro-chefe do Instituto Astronômico e Meteorológico, setor que dirigiria até sua morte, em 1929; de 1925 a 1929, Coussirat Araújo acumularia também a direção do Departamento Central da Escola. Pioneiro da moderna meteorologia brasileira, participou de várias viagens, comissionado pela escola e pelas autoridades brasileiras, de estudo aos Estados Unidos, de onde trazia parte das inovações aplicadas no Instituto. Em 1921-1922, a convite do governo do estado de Minas Gerais, dirigiria os trabalhos de reorganização do serviço meteorológico daquele estado.

Outros quatro ex-alunos formados até 1930 não seguiram carreira docente mas sim na administração pública estadual (SOP e outras secretarias), e acabaram chegando à chefia da Prefeitura Municipal, em período posterior àquele analisado neste artigo. Todos eles - Ivo Wolff, Egídio Costa, Lindolfo Boehl e Ildo Meneghetti - chegaram à prefeitura de forma indireta, nomeados pelo 
interventor federal ou pelo governador do estado (Hassen; Ferreira, 1996, p.117). Meneghetti seria também eleito prefeito em 1951 e depois, por duas vezes, eleito governador do estado do Rio Grande do Sul, em 1955 e 1963. Wolff e Costa foram nomeados entre novembro de 1945 e novembro de 1946, quando não se realizavam eleições para prefeito da capital; Boehl, na condição de presidente da Câmara dos Vereadores, assumiu na vacância do cargo pela saída de Meneghetti para o governo do estado, entre julho e setembro de 1954. Pode-se citar ainda a carreira de Leonel de Moura Brizola, engenheiro civil da turma de 1949, prefeito de Porto Alegre, governador do Rio Grande do Sul, deputado federal por esse estado e pela Guanabara, duas vezes governador do Rio de Janeiro e por diferentes ocasiões candidato à presidência da República.

\section{CONSIDERAÇÕES FINAIS}

Neste texto propusemos refazer alguns percursos de professores da Escola de Engenharia em sua relação com a administração pública e com a política regional durante a Primeira República, estabelecendo certos nexos entre as trajetórias profissionais e políticas. Primeiro, os docentes da Escola de Engenharia conformam um 'grupo novo', surgido do ambiente republicano anterior à queda da monarquia, e não representam a continuidade com os setores presentes na administração antes do advento da República. Com efeito, as circunstâncias descritas do afastamento do primeiro diretor da Escola, Álvaro Nunes Pereira, reforçam essa percepção. Segundo, os membros do núcleo fundador e dos primeiros anos de existência da Escola possuem características que os distinguem de outros engenheiros: a origem militar ou próxima dos meios militares; formação predominantemente no Rio de Janeiro, na Escola Central (Politécnica) ou na Escola Militar; e o positivismo e o militantismo republicano como traço cultural/ideológico agregador. Terceiro, a migração dos quadros da Escola para a Secretaria de Obras Públicas, e desta para a Escola, é permanente durante o período, mas não se pode afirmar que a carreira dos engenheiros-funcionários parta da Escola para a Secretaria: a administração é um espaço de atuação importante, decisivo talvez, mas essa elite em formação segue tendo na Escola seu núcleo identitário forte. Assim, mesmo as carreiras mais bem-sucedidas politicamente são estruturadas em paralelo ao vínculo escolar, nunca se afastando completamente dele. Quarto, a Escola de Engenharia desenvolve e estrutura uma rede de ensino (e de relações) que será decisiva para a administração regional nas décadas de 1910 e 1920, garantindo o desenho institucional para a área educacional e tecnológica a ser incorporado pelo estado nas décadas sub- 
sequentes. Se é verdade que o estado apoia financeiramente a Escola, também o é que é a Escola de Engenharia que proporciona à administração regional um esboço das instituições a serem por ela assumidas.

Por fim, uma palavra sobre a ideia de Bosi acerca da matriz positivista sulina na configuração do Estado brasileiro pós-1930 e sua relação com os resultados aqui apresentados. Entendemos que a comprovação empírica da tese de Bosi só poderá ser feita através de uma agenda ampla de pesquisa que combine a realização de uma genealogia das agências federais - e a prosopografia de seus agentes -, dos primeiros quinze anos de governo de Vargas, com o estudo da gênese das políticas públicas desenvolvidas no período. Todavia, os indícios presentes neste trabalho apoiam o sentido geral da proposição de Bosi. Com efeito, é provável que os acontecimentos em curso no sul do país já sinalizassem para a conformação social e ideológica de uma elite de funcionários e de homens públicos, ligados às questões do Estado e tendo em comum certo distanciamento do mundo da elite liberal e de seus quadros mentais. Nem mais ou mais bem preparados para interpretar necessidades e indicadores de mudança da sociedade brasileira do que outros grupos regionais nacionais, os indivíduos dessa elite em formação souberam, isto sim, aproveitar-se das circunstâncias históricas em que se viram envolvidos, como a possibilidade de relativa autonomia da vida política local e do espaço institucional da Escola em face do poder social das elites proprietárias; o compartilhamento de experiências com outra instituição fortemente 'autônoma', a militar; a convergência de propósitos com um poder executivo forte e centralizador e o acesso direto a seus recursos; por fim, a experiência cultural comum do positivismo e a defesa do primado da técnica - e das virtudes da transformação pela técnica - sobre a tradição 'literária' brasileira. Estas características não afetavam ou estavam presentes em todos os indivíduos envolvidos com a administração pública no sul do Brasil, nas primeiras décadas do século XX, mas sim em uma parte ativa e particularmente bem posicionada deles, e a Escola de Engenharia foi seu espaço de gestação profissional, intelectual e política. A análise das carreiras desses indivíduos, como no caso de João Lüderitz - primeiro presidente do Departamento nacional do Senai, egresso e professor da Escola, por cerca de quinze anos diretor do Instituto Técnico Profissional e com passagem pelo secretariado do estado no final da Primeira República -, pode vir a reforçar as conexões entre formação e percurso profissional e regional e o sucesso na trajetória nacional. 


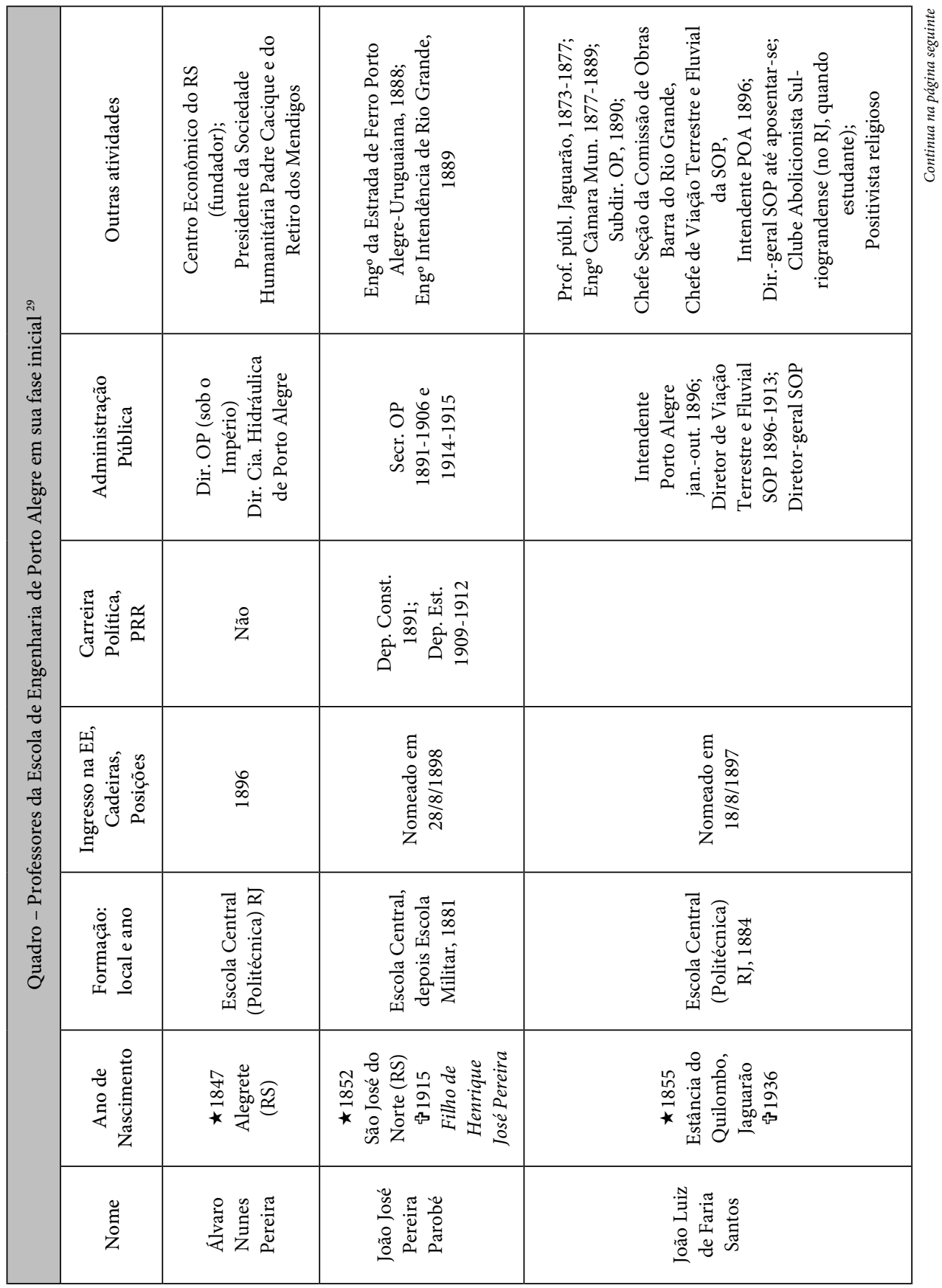


Positivistas e republicanos...

\begin{tabular}{|c|c|c|c|}
\hline 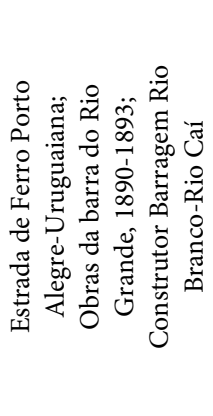 & 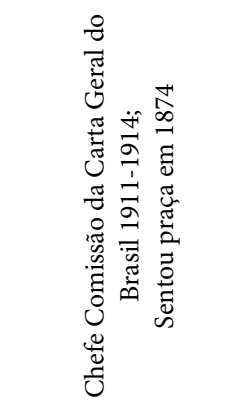 & 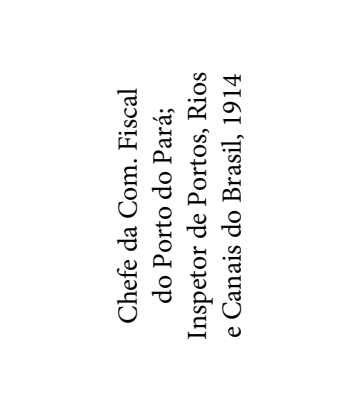 & 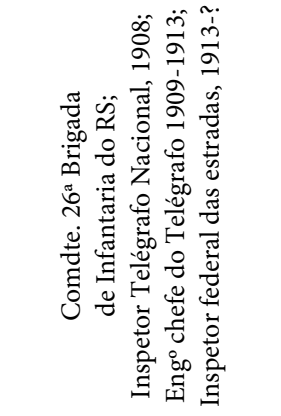 \\
\hline \multirow[t]{2}{*}{ 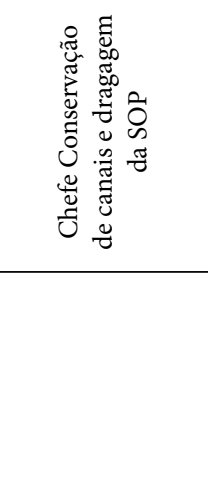 } & & 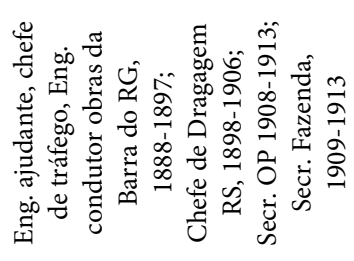 & 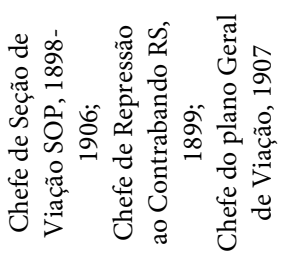 \\
\hline & 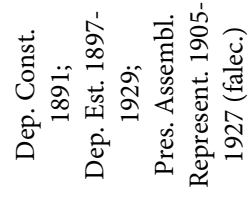 & & \\
\hline \multirow[t]{2}{*}{ 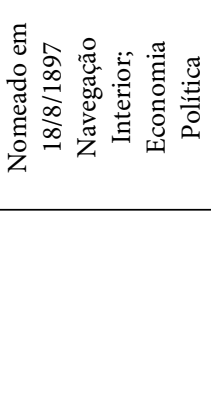 } & 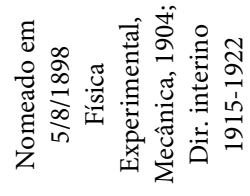 & 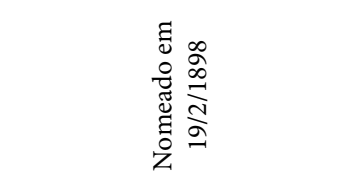 & 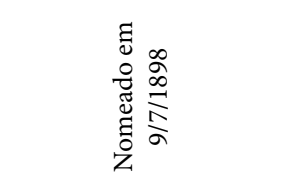 \\
\hline & 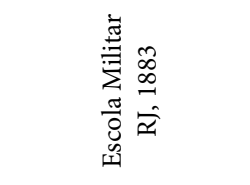 & 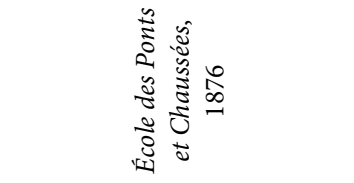 & 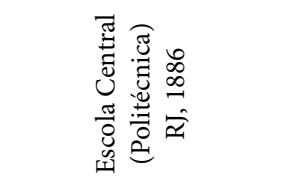 \\
\hline 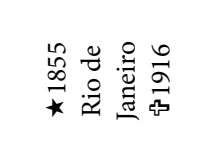 & 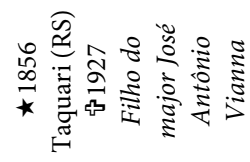 & 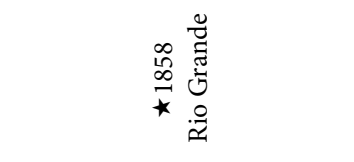 & 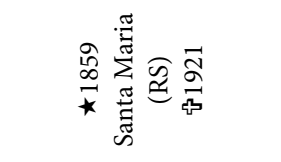 \\
\hline 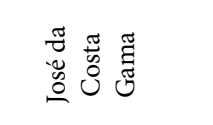 & 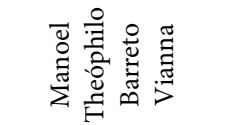 & 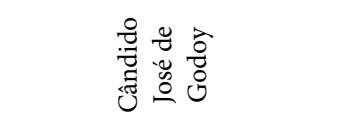 & 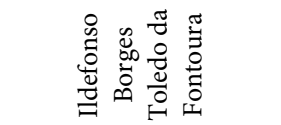 \\
\hline
\end{tabular}




\begin{tabular}{|c|c|c|c|c|c|}
\hline & & 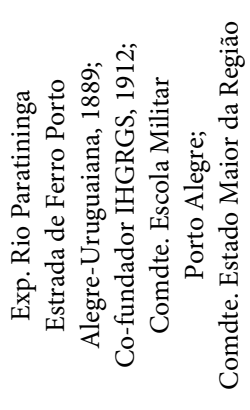 & 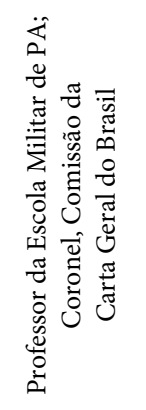 & 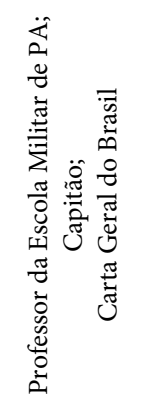 & 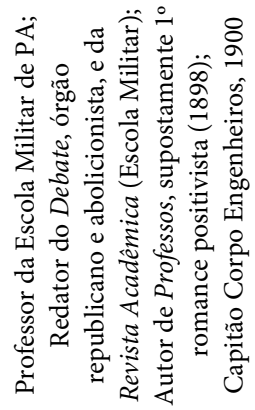 \\
\hline \multirow[t]{2}{*}{ 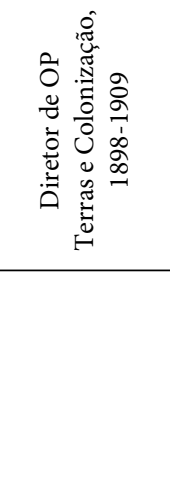 } & & & & & 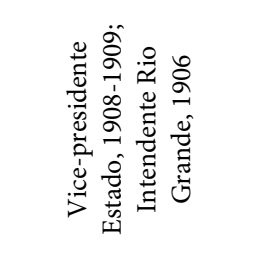 \\
\hline & 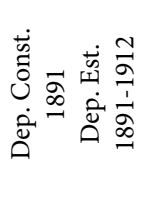 & & & & 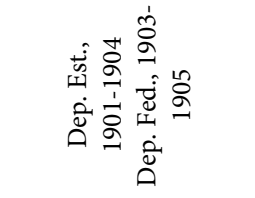 \\
\hline 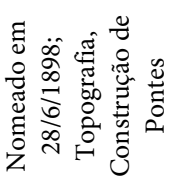 & 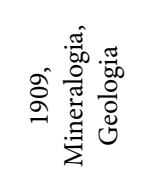 & 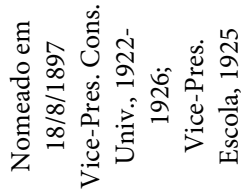 & 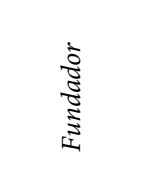 & $\frac{1}{\frac{1}{3}}$ & 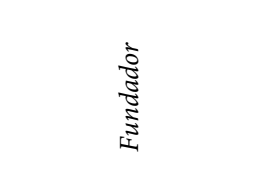 \\
\hline 苟 & 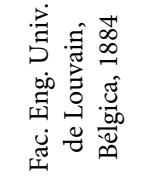 & 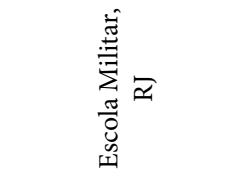 & 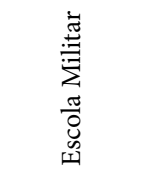 & 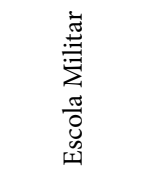 & 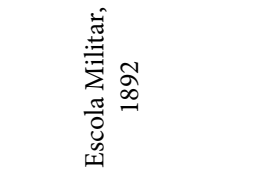 \\
\hline 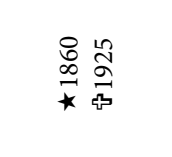 & 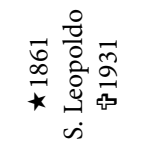 & 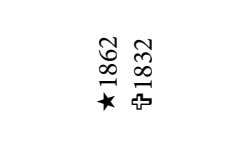 & 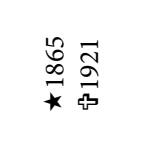 & 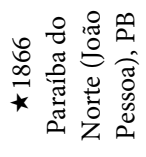 & 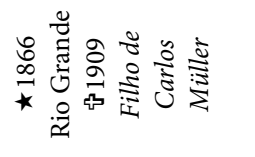 \\
\hline 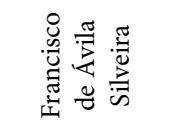 & 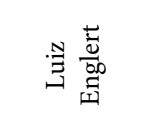 & 莺 & 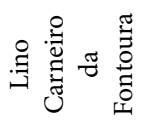 & 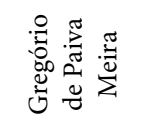 & 恚恚离 \\
\hline
\end{tabular}


Positivistas e republicanos...

\begin{tabular}{|c|c|c|c|}
\hline 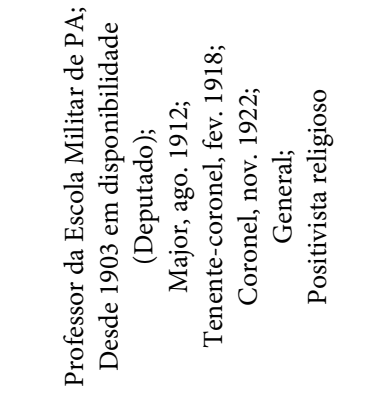 & & 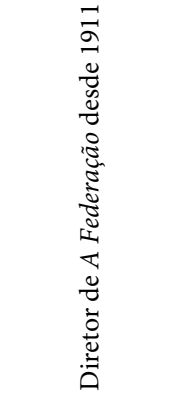 & 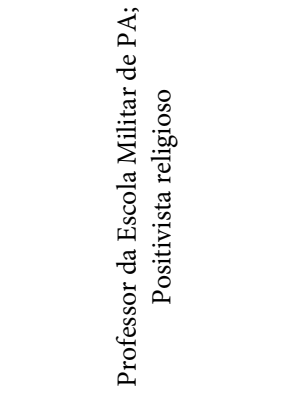 \\
\hline 芯芯 & 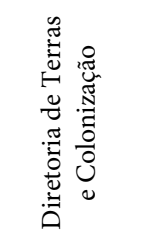 & 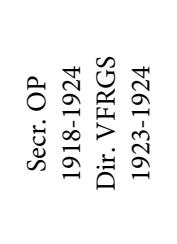 & 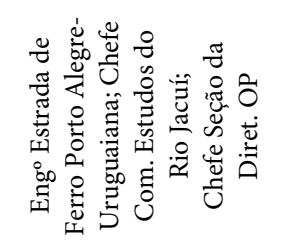 \\
\hline 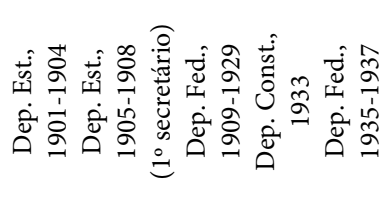 & & 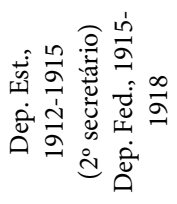 & 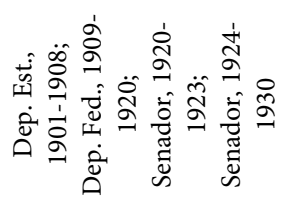 \\
\hline 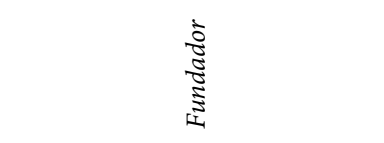 & 홍 & 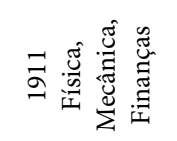 & 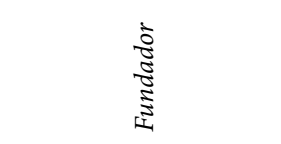 \\
\hline 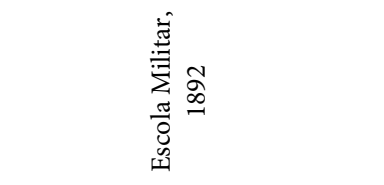 & 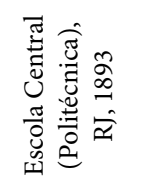 & 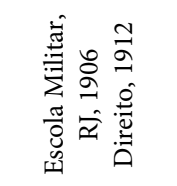 & 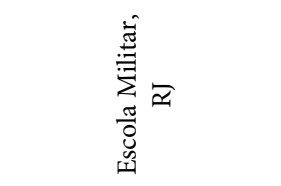 \\
\hline 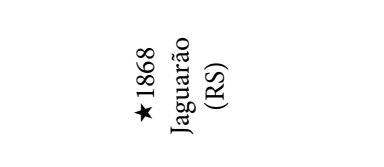 & 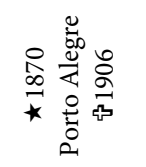 & 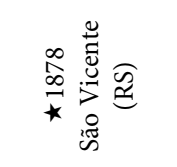 & 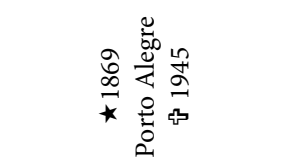 \\
\hline 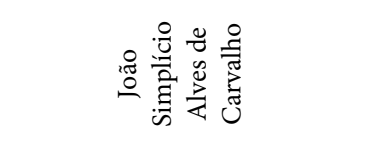 & 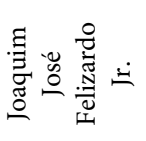 & 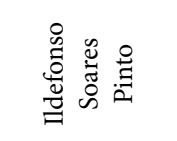 & 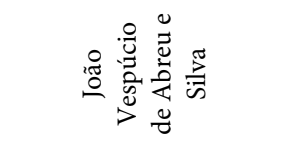 \\
\hline
\end{tabular}




\section{NOTAS}

${ }^{1}$ Diretor do Departamento Meteorológico Nacional, por ocasião do falecimento de Ladislau Coussirat Araújo, pioneiro da moderna meteorologia brasileira e professor da Escola de Engenharia de Porto Alegre. "Coussirat Araújo e a Meteorologia Brasileira", Jornal do Commercio, 10 dez. 1929, reproduzido em Egatea, v.XV, 1930, n.1-2, p.3.

${ }^{2}$ Uma versão preliminar deste texto foi apresentada nas Jornadas "Elites intelectuales y formación del Estado", Universidad San Andrés/Idaes/Ides, Buenos Aires, em abril de 2009. O autor agradece os comentários de René Gertz e de Paulo Pezat à versão final do texto.

${ }^{3}$ BOSI, Alfredo. "A Arqueologia do Estado-providência: sobre um enxerto de ideias de longa duração”. In: . Dialética da colonização. São Paulo: Companhia das Letras, 1992. p.273-307.

${ }^{4}$ Fundado em 1882, o PRR foi a força hegemônica da política regional durante toda a Primeira República, passando por contestações episódicas em 1891-92, entre 1893-1895 e durante a chamada Revolução de 1923. Era chefiado por Júlio Prates de Castilhos (1860-1903), que foi deputado à Constituinte Nacional e autor da carta constitucional estadual de 14/7/1891, tendo dirigido o estado entre 1892 e 1897 . Autoritarismo governamental, intervencionismo econômico, disciplina férrea imposta aos militantes republicanos, defesa ideológica das virtudes da ditadura científica positivista e combate sistemático à dissidência e à oposição foram algumas das características de sua política. Castilhos foi sucedido por Antônio Augusto Borges de Medeiros, herdeiro e propagandista de sua obra política; a Revolução Federalista colocou frente a frente o campo governamental e o Partido Federalista, criado em 1892, e estendeu-se entre os anos de 1893 e 1895. O Partido Federalista havia recuperado um contingente significativo das antigas lideranças que, sob a monarquia, dirigiram o Partido Liberal e controlaram a política na Província do Rio Grande.

${ }^{5}$ Como o mostraram cabalmente Joseph Love e Bert Barickman, com base no cotejo de três amostras regionais - São Paulo, Minas Gerais e Pernambuco - de membros da elite política republicana (num total de 753 indivíduos), "apenas $42 \%$ eram republicanos 'históricos', isto é, aqueles que eram favoráveis à mudança de Regime antes da queda do Império $(\mathrm{N}=268)$. Os outros $58 \%$ eram adesistas que se converteram ao republicanismo depois que a República se tornou um fato, presumivelmente para continuar a habilitar-se a postos políticos. (Variações regionais eram notáveis, como uma maioria de 'históricos' entre os paulistas, contra apenas $28 \%$ entre os pernambucanos.)" (LOVE, Joseph; BARICKMAN, Bart. "Elites regionais". In: HEINZ, Flavio M. (Org.). Por outra história das elites. Rio de Janeiro: Ed. FGV, 2006. p.78-79). É possível supor uma esmagadora maioria de 'históricos' também entre os republicanos rio-grandenses, mas essa análise ainda está por ser realizada.

${ }^{6}$ Ver, a esse respeito, TRINDADE, Helgio. "O jacobinismo castilhista e a ditadura positivista no Rio Grande do Sul". In: (Org.). O Positivismo: teoria e prática - sesquicentenário da morte de Augusto Comte. Porto Alegre: Ed. UFRGS, 2007. p.485-497. 
${ }^{7}$ CARVALHO, José Murilo de. A formação das almas: o imaginário da República no Brasil. São Paulo: Companhia das Letras, 1990. p.28.

${ }^{8}$ Vários autores têm buscado restabelecer o sentido da ação do estado rio-grandense pelo viés da análise de sua agenda de intervenção e políticas públicas. Fundamentados em farta documentação de natureza econômica, sustentaram a originalidade e o caráter 'socialmente avançado' das políticas públicas dos governos republicanos do sul, conectando-as à presença doutrinária do positivismo na formação de seus dirigentes. Invariavelmente, destacam a existência de uma direção política e um funcionalismo relativamente autônomo em relação a demandas dos grupos sociais dominantes, notadamente as tradicionais elites agrárias das regiões da fronteira sul do estado, que haviam governado durante o período monárquico. As bases dessa vertente historiográfica foram assentadas em FRANCO, Sérgio da Costa. Júlio de Castilhos e sua época. Porto Alegre: Ed. da Universidade, 1968, e, sobretudo, na tese de LOVE, Joseph. O Regionalismo gaúcho e as origens da revolução de 1930. São Paulo: Perspectiva, 1975. Recentemente, as linhas gerais dessa vertente podem ser encontradas nas teses de TARGA, Luiz Roberto Pecoits. Le Rio Grande do Sul et la création de l'État "développementiste" brésilien. Tese (Doutorado em ciências econômicas) - Université Pierre Mendes France. Grenoble, 2002, e de HERRLEIN JR., Ronaldo. Rio Grande do Sul, 1889-1930: um outro capitalismo no Brasil meridional? Tese (Doutorado em Economia) - Unicamp. Campinas (SP), 2000. Em contraponto a essa perspectiva, e criticando seu caráter acentuadamente particularista, Gunter Axt atenta, com muita propriedade, para a complexidade do processo político regional, marcado pelos arranjos políticos locais e pela variável coronelística. Tal como os autores já citados, o foco da atenção de Axt são as políticas públicas do Rio Grande do Sul, mas, numa posição diametralmente oposta à deles, sugere que está na análise da ação dos grupos de pressão e da acomodação entre setores dirigentes e frações da classe dominante, e não na filiação doutrinária ao positivismo, a chave para a compreensão das origens do intervencionismo público na Primeira República. AXT, Günter. Gênese do Estado democrático-burguês no Rio Grande do Sul (1889-1929). Tese (Doutorado) - USP. São Paulo, 2001. Um balanço desse debate historiográfico foi feito por HEINZ, Flavio M. "Elites, estado y reforma en Uruguay y Brasil meridional: castilhismo y batllismo en perspectiva comparada. El caso de las elites de Rio Grande do Sul en la transición del siglo XIX al XX. In: REGUERA, Andrea (Org.). Los rostros de la modernidad: vías de transición al capitalismo. Europa y América Latina, siglos XIX y XX. Rosario: Prohistoria Ed., 2006. p.112-135.

9 DIAS José Luciano de Mattos, “Os engenheiros do Brasil”. In: GOMES, Angela Castro. Engenheiros e economistas: novas elites burocráticas. Rio de Janeiro: Ed. FGV, 1994, p.1381; nota 7, p.67. Para uma ideia geral sobre a presença dos engenheiros na burocracia e na sociedade nacional, ver, além dessa obra, COELHO, Edmundo Campos. As profissões imperiais: medicina, engenharia e advocacia no Rio de Janeiro, 1822-1930. Rio de Janeiro: Record, 1999. Recentemente, vários trabalhos recuperaram diferentes aspectos da formação e organização dos engenheiros, bem como colocaram em evidência as relações entre ciência, técnica e participação política durante o Segundo Reinado e a Primeira República. Para citar apenas alguns, assinalamos os trabalhos de MARINHO, Pedro Eduardo Mesqui- 
ta de Monteiro. 'O Centauro Imperial e o 'partido' dos engenheiros: a contribuição das concepções gramscianas para a noção de Estado ampliado no Brasil”. In: MENDONÇA, Sonia Regina (Org.). Estado e historiografia no Brasil. Niterói: Ed. UFF; Faperj, 2006. p.5570; "De politécnicos a engenheiros: a engenharia entre a sociedade civil e a sociedade política no Brasil oitocentista". In: ALMEIDA, Marta; VERGARA, Moema (Org.). Ciência, história e historiografia. São Paulo: Via Lettera; Rio de Janeiro: Mast, 2008. p.13-24; e "Engenharia e política: os engenheiros entre a sociedade civil e a sociedade política”. In: SIMPÓSIO NACIONAL DE HISTÓRIA, 24. Anais... S.l.: Associação Nacional de História (Anpuh), 2007. 8p.; as teses de doutorado: SOUZA, Ana Cláudia Ribeiro de. Escola Politécnica e suas múltiplas relações com a cidade de São Paulo, 1893-1933. São Paulo: PUC-SP, 2006; e SILVA, Tania Soares da. Paula Souza, "arauto da modernidade": um estudo da elite paulista, 1843-1917. São Paulo: PUC-SP, 2009.

${ }^{10}$ Participaram da fundação os engenheiros militares João Simplício Alves de Carvalho, João Vespúcio de Abreu e Silva, Juvenal Octaviano Miller, Lino Carneiro da Fontoura e Gregório Paiva, todos militares. Em seguida se juntaram a eles Álvaro Nunes Pereira, José Marques Guimarães e Alfredo Leal (diretor da Escola de Farmácia). Sobre a Escola de Engenharia podemos citar o livro comemorativo de HASSEN, Maria de Nazareth; FERREIRA, Maria Letícia Mazzucchi. Escola de Engenharia/UFRGS: um século. Porto Alegre: Tomo Editorial, 1996. Muito documentados e informativos são os relatórios de pesquisa de FRANCO, Maria Estela Dal Pai; MOROSINI, Marília Costa. "A Escola de Engenharia (1896-1922) e o Partido Republicano Riograndense (PRR): hegemonia Estado-universidade". In: FRANCO, Maria Estela; MOROSINI, Marília; LEITE, Denise. Relatório de Pesquisa I - A UFRGS em sua gênese e as ingerências do Estado: a Escola de Engenharia, a Faculdade de Medicina e a Faculdade de Direito (1896-1930). Porto Alegre, 1992; e A Universidade Técnica: cultura antecipativa na Escola de Engenharia de Porto Alegre (19221934). Porto Alegre: PPGEdu; PPGSociologia, 1993. Sínteses sobre a história da Escola de Engenharia podem ser encontradas em MACEDO, Francisco Riopardense de. História das profissões da área tecnológica do Rio Grande do Sul. Porto Alegre: Crea-RS, 1993; e SOARES, Mozart Pereira. O Positivismo no Brasil: 200 anos de Augusto Comte. Porto Alegre: AGE; Ed. da Universidade, 1998. De resto, uma série de crônicas da história da Escola podem ser encontradas em diferentes edições da revista Egatea (1914-1930) e nos próprios relatórios anuais da Escola. Essa 'memória' dos membros da Escola está na origem do relato apresentado em várias das obras aqui citadas. Mais recentemente, surgiu ALVES, Leonice Aparecida de Fátima. Estado, educação e modernização agrária: o papel da Escola de Engenharia de Porto Alegre (1889-1930). São Leopoldo: Ed. Unisinos, 2008. A obra enfoca aspectos da ação da Escola na expansão da educação agrícola no Rio Grande do Sul.

${ }^{11}$ BOEIRA, Nelson Fernando "O Rio Grande de Augusto Comte". In: GONZAGA, Sergius (Org.). RS: Cultura e ideologia. Porto Alegre: Mercado Aberto, 1980. p.34-59. p.57. Do mesmo autor, ver também a tese de doutoramento Comte in exile: the origins of political positivism in Rio Grande do Sul, Brazil, 1860-1891. Ph.D. dissertation - Yale University. New Haven (Conn.), 1991. 
12 GERTZ, René. O aviador e o carroceiro: política, etnia e religião no Rio Grande do Sul dos anos 1920. Porto Alegre: Edipucrs, 2002. p.152.

${ }^{13}$ Para SOARES (1998, p.195), “o Land Grant College, já seguido com notável êxito pelos Estados Unidos da América do Norte ... associava o ensino técnico à pesquisa científica, e à extensão rural (ou urbana, conforme o caso). Os conhecimentos hauridos na investigação seguiam dois caminhos: através do professor atingiram as salas de aula, e por meio dos agentes especializados de informação (os extensionistas) chegavam ao povo. Assim, tanto as casas de ensino quanto a comunidade falariam a mesma linguagem. Os núcleos didáticos não se encontravam superpostos à sociedade, mas profundamente entrelaçados com o tecido social".

14 WADDELL; BARRINGTON. “A Engenharia como profissão”. Egatea, v.II, n.3, p.142143, nov.-dez. 1915. p.142.

${ }^{15} \mathrm{O}$ decreto 7.566, de 23 set. 1909, criaria formalmente o ensino profissionalizante no país, através da edificação de escolas de aprendizes e artífices nas capitais estaduais. Sobre o ensino técnico-profissional no sul do país e o Instituto Parobé, ver: LIMA, Raquel Rodrigues de. As Escolas de Arte e Ofícios do Rio Grande do Sul: 1900 a 1930. Dissertação (Mestrado) - UFRGS. Porto Alegre, 1997; e STEPHANOU, Maria. Forjando novos trabalhadores: a experiência do ensino técnico-profissional no Rio Grande do Sul, 1890-1930. Dissertação (Mestrado em Educação) - UFRGS. Porto Alegre, 1990.

16 "Relatório da Escola de Engenharia de Porto Alegre referente ao anno de 1907, apresentado ao Conselho Escolar em 2 de abril de 1908 pelo Diretor Engo João José Pereira Parobé", p.5.

17 "Relatório da Escola de Engenharia de Porto Alegre referente ao anno de 1907”, op. cit., p.8.

${ }^{18}$ Uma listagem dos professores ativos na Escola de Engenharia, presente no Relatório do Anno de 1901, apontou os seguintes nomes (para alguns não foi possível encontrar informações biográficas): Lino Carneiro da Fontoura, João José Pereira Parobé, Gregório de Paiva Meira, João Simplício Alves de Carvalho, Francisco de Ávila Silveira; Manoel Theóphilo Barreto Vianna; João Luiz de Faria Santos, Cândido José de Godoy; João Vespúcio de Abreu e Silva, Joaquim José Felizardo Júnior, Juvenal Octaviano Müller, João Maria Paldaof, Benjamin Torres, Frederico Gambara, José da Costa Gama, Cel. Cherubim Febeliano da Costa. Em seguida, a coleta de dados biográficos desses indivíduos deu-se com base na consulta de amplo número de dicionários biográficos, revistas, relatórios e outras fontes, constituindo a base de informações sobre a qual trabalhamos: Relatórios anuais da Escola de Engenharia de Porto Alegre, de 1898-1913; ABREU, Alzira et al. (Coord.). Dicionário histórico-biográfico brasileiro pós 1930. Rio de Janeiro: Ed. FGV, 2001; PIANTA, Dante. Personalidades rio-grandenses. Porto Alegre, 1962; REIS, Carlos A. (Org.). Album do Rio Grande do Sul. Porto Alegre, 1905; TIMM, Otacílio; GONZALEZ, Eugênio (Org.). Album Illustrado do Partido Republicano Castilhista. Porto Alegre: Livraria Selbach, 1932; revista EGATEA (15v., de 1914 a 1930); BOLETIM da Sociedade de Engenharia do Rio Grande do Sul, 1932 a 1938, n.1 a 24; e SPALDING, Walter. "Propaganda e propagandistas republica- 
nos no Rio Grande do Sul". Revista do Museu Júlio de Castilhos e Arquivo Histórico do Estado do Rio Grande do Sul, Porto Alegre, ano I, n.1, p.57-136, jan. 1952. Por fim, foram consultadas no Arquivo Histórico do Exército (AHEX), no Rio de Janeiro, as Fés de Ofício dos militares e engenheiros João José Pereira Parobé; João Simplício Alves de Carvalho; Lino Fontoura, Juvenal Octaviano Müller, Manoel Theóphilo Barreto Vianna e Gregório de Paiva Meira.

${ }^{19}$ A SOP estava organizada, segundo o organograma funcional de 1895, em três diretorias: Central, encarregada das administração da pasta e gestão de pessoal; de Obras Públicas, Terras e Colonização, encarregada da infraestrutura e da gestão do processo imigratório e de terras indígenas; e de Viação, responsável pela infraestrutura dos transportes fluvial e ferroviário e da abertura e manutenção de estradas. As duas diretorias 'operativas' dispunham de chefes de seção, ajudantes e condutores, além do pessoal de escritório. Uma reforma em 1907 separaria a Diretoria de Obras Públicas, Terras e Colonização, criando uma Diretoria de OP e uma Diretoria de Terras e Colonização, especializando funções (com novas chefias internas) e elevando para quatro o número de diretorias da SOP. No organograma de 1914 desaparece a Diretoria Central, substituída por uma Seção de expediente, e a Diretoria de Viação é dividida em Diretoria de Viação Fluvial e Diretoria de Viação Terrestre, além de se assinalar a existência de uma Seção de Desenho. Finalmente, no organograma de pessoal de 1929/1930 há quatro diretorias, além da Seção de Expediente, que passa a ser coordenada por um diretor: Diretoria de Obras Públicas; Diretoria de Agricultura, Indústria e Comércio, subdividida em seções de Agricultura, Indústria Animal, Terras e Colonização e Deologia e Mineralogia; Diretoria de Viação Fluvial; e Diretoria de Viação Terrestre.

${ }^{20}$ Neste total estão incluídos os secretários de Obras Públicas, diretores, subdiretores, chefes de seção, engenheiros, ajudantes, condutores e escriturários. Ficaram fora desta totalização cargos subalternos tais os de guarda, contínuos e auxiliares de serviços gerais. Estes dados sobre o conjunto de funcionários da SOP foram pesquisados nos Relatórios anuais da Secretaria dos Negócios de Obras Públicas, no projeto "Elites Governantes, Orientação Intelectual e Formação de Políticas Públicas: Perfil e Ação dos Dirigentes do Partido Republicano Rio-grandense (RS: 1891-1930)", que obteve apoio de bolsa de iniciação à pesquisa - bolsista Ana Paula Korndörfer - da Fapergs, em 2002-2003.

${ }^{21}$ Outra faceta de João Simplício Alves de Carvalho seria sua 'germanofilia'. Segundo GERTZ (2002, p.156), ele seria o único nome não-alemão a participar da Bismarckrunde de Porto Alegre, o 'círculo bismarckiano' que reunia parte da elite de descendência alemã do estado todo dia $1^{\circ}$ de abril, a partir de 1909, para festejar o aniversário de Bismarck. O autor cita também o nome do Gal. Manoel Theóphilo Barreto Vianna, diretor da Escola de Engenharia por muitos anos e, por mais de duas décadas, presidente da Assembleia de Representantes do Rio Grande do Sul, e que teria tido influência na decisão governamental de reprimir as violentas manifestações antialemãs em Porto Alegre, ocorridas a partir de abril de 1917. Embora não seja nosso propósito explorar este tema aqui, é certo, como mostrou Gertz, que os vínculos da Escola de Engenharia com a Alemanha, e com as populações de origem alemã que viviam no Rio Grande do Sul, foram importantes para fazer 
dela, "pelo menos até 1930, a mais 'germânica' das instituições de ensino superior do estado" (GERTZ, 2002, p.159). O Instituto de Eletrotécnica, criado em 1908, por exemplo, possuía um número muito expressivo de estrangeiros entre seus professores (contratados diretamente na Europa - notadamente na Alemanha -, para as devidas funções), o que parece não ter acontecido nos primeiros cursos da Escola, de engenheiro de estradas e engenheiro civil, majoritariamente ministrados por egressos da Escola Central (Politécnica) do Rio de Janeiro.

${ }^{22}$ PEZAT, Ricardo Paulo. "A ortodoxia positivista sul-rio-grandense e a Secretaria de Obras Públicas". In: GRAEBIN, Cleusa Maria; LEAL, Elisabete. Revisitando o positivismo. Canoas: La Salle, 1998. p.145.

${ }^{23}$ LEAL, Elisabete. Os filósofos em tintas e bronze: arte, positivismo e política na obra de Décio Villares e Eduardo de Sá. Tese (Doutorado) - UFRJ. Rio de Janeiro, 2006. p.254.

${ }^{24}$ Estes comentários foram feitos a partir da lista reproduzida por SOARES (1998, p.180182), do original pertencente à Biblioteca da Capela Positivista de Porto Alegre.

${ }^{25}$ CASTRO, Celso. Os militares e a República: um estudo sobre cultura e ação política. Rio de Janeiro: Zahar, 1995. p.130.

${ }^{26}$ Fé de Ofício do Coronel João Simplício Alves de Carvalho. AHEX, V, 20, 8, folha 2.

${ }^{27}$ Fé d'offício do Cidadão Primeiro-tenente Juvenal Octaviano Müller [1893] AHEX, V, 3, 53 , folha 8 .

${ }^{28}$ PEZAT, Paulo. "Juvenal Miller e a difusão do positivismo nos primórdios da República". In: ALVES, Francisco das Neves (Org.). Por uma história multidisciplinar do Rio Grande. Rio Grande: Furg, 1999. p.189.

${ }^{29}$ Listagem incompleta dos professores ativos, com base no Relatório do Anno de 1901. Foram incluídos os nomes dos Engenheiros Luiz Englert (período posterior) e Ildefonso Soares Pinto (em licença em 1901).

Artigo recebido em outubro de 2009. Aprovado em outubro de 2009. 
